\title{
THE
}

\section{Investigation of the Lithium Solid Electrolyte Interphase in Vinylene Carbonate Electrolytes Using Cu||LiFePO 4 Cells}

\author{
Zachary L. Brown \\ University of Rhode Island \\ Sunhyung Jurng \\ University of Rhode Island \\ Brett L. Lucht \\ University of Rhode Island, blucht@uri.edu
}

Follow this and additional works at: https://digitalcommons.uri.edu/chm_facpubs

Creative Commons License

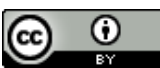

This work is licensed under a Creative Commons Attribution 4.0 License.

\section{Citation/Publisher Attribution}

Brown, Z. L., Jurng, S., \& Lucht, B. L. (2017). Investigation of the Lithium Solid Electrolyte Interphase in Vinylene Carbonate Electrolytes Using Cul|LiFePO 4 Cells. J. Electrochem. Soc., 164(9), A2186-A2189. doi: 10.1149/2.0021712jes

Available at: http://dx.doi.org/10.1149/2.0021712jes

This Article is brought to you for free and open access by the Chemistry at DigitalCommons@URI. It has been accepted for inclusion in Chemistry Faculty Publications by an authorized administrator of DigitalCommons@URI. For more information, please contact digitalcommons-group@uri.edu. 


\title{
Investigation of the Lithium Solid Electrolyte Interphase in Vinylene Carbonate Electrolytes Using $\mathrm{Cu}|| \mathrm{LiFePO}_{4}$ Cells
}

\author{
Zachary L. Brown, ${ }^{*}$ Sunhyung Jurng, ${ }^{*}$ and Brett L. Lucht**,z \\ Department of Chemistry, University of Rhode Island, Kingston, Rhode Island 02881, USA
}

\begin{abstract}
The influence of vinylene carbonate (VC) on the plating/stripping of lithium was investigated using $\mathrm{Cu}|| \mathrm{LiFePO} 4 \mathrm{Cell}_{\mathrm{s}}$. These cells allow for easy fabrication and in-situ generation of lithium, with no excess lithium to influence performance. Addition of VC to the electrolyte improves both capacity retention and efficiency. IR and XPS spectroscopy of the surface of the plated lithium suggests the presence of a significant amount of poly $(\mathrm{VC})$ when the electrolyte (1.2 M LiPF 6 in ethylene carbonate (EC): ethyl methyl carbonate (EMC) $(3: 7, \mathrm{vol}))$ contains $5 \%$ of added VC. This suggests employing additives that generate polymeric species on the surface of lithium improves plating/stripping performance in carbonate electrolytes.

(C) The Author(s) 2017. Published by ECS. This is an open access article distributed under the terms of the Creative Commons Attribution 4.0 License (CC BY, http://creativecommons.org/licenses/by/4.0/), which permits unrestricted reuse of the work in any medium, provided the original work is properly cited. [DOI: 10.1149/2.0021712jes] All rights reserved.

(cc) BY
\end{abstract}

Manuscript submitted June 5, 2017; revised manuscript received July 11, 2017. Published July 29, 2017.

The plating and stripping of the lithium metal negative electrode in non-aqueous electrolytes has been investigated for decades. ${ }^{1-3}$ In particular, carbonate solvents have relatively high voltage stability, making them desirable electrolytes for high-energy density lithium batteries. $^{3-6}$ However, the efficiency of plating/stripping lithium in carbonate electrolytes does not meet requirements for commercial application $(>99.9 \%)^{7,8}$

It is common to measure the plating/stripping efficiency of lithium by assembling $\mathrm{Li}|| \mathrm{Cu}$ cells. ${ }^{9-13}$ In this cell design, a small amount of $\mathrm{Li}$ is cycled, with an excess reservoir of lithium present. One limitation of this cell design is the difficulty of controlling the design and construction of the solid electrolyte interphase ${ }^{14}$ (SEI) on lithium, as the low reduction potential of the lithium metal electrode present during cell construction will cause immediate reaction with electrolyte upon exposure. Thus, a reaction between the electrolyte and the lithium metal electrode will occur before cycling begins. Further, the excess lithium within the cell can significantly increase the cycle life of the cell making it difficult to compare to commercial cells, with a limited supply of lithium.

Contrary to $\mathrm{Li}|| \mathrm{Cu}$ cells, $\mathrm{Cu}|| \mathrm{LiFePO}_{4}$ cells have air-stable components, facilitating their processing and assembly. ${ }^{15,16}$ Further, the in-situ formation of lithium metal and low reactivity of $\mathrm{LiFePO}_{4}$ ensures additives under investigation do not react with the electrode surface upon construction and are only reduced upon initial cycling. This affords the possibility for controlled design and construction of the SEI on lithium metal since the reduction of the electrolyte can be controlled by current density, cell potential, and the quantity of lithium plated. Finally, given that there is no excess lithium in $\mathrm{Cu}|| \mathrm{LiFePO}_{4}$ cells, any observed improvements in capacity retention, Coulombic efficiency, or impedance should be applicable to other lithium metal based battery systems.

Vinylene carbonate (VC) is a well known electrolyte additive for lithium-ion batteries, demonstrating exceptional performance for graphite and several cathode materials. ${ }^{17-24}$ Further, the reaction products of VC with lithium have been investigated in detail, using $\mathrm{Li}|| \mathrm{Ni}$ cells $^{25-27}$ and $\mathrm{Li} \| \mathrm{Cu}$ cells, ${ }^{10,28}$ and found to have beneficial performance, typically attributed to poly(VC) within the SEI. However, the effect of added VC has not been investigated with lithium metal anodes in cells without a large excess of lithium. Herein, $\mathrm{Cu}|| \mathrm{LiFePO}_{4}$ cells are utilized to investigate the influence of $\mathrm{VC}$ for plating and stripping lithium.

\section{Experimental}

Electrochemistry.-Electrochemical characterization was performed using 2032 coin cells containing $\mathrm{Cu}|| \mathrm{LiFePO}_{4}$. A minimum of

\footnotetext{
*Electrochemical Society Student Member.

**Electrochemical Society Member.
}

zE-mail: blucht@chm.uri.edu two cells were assembled for each electrolyte, consisting of a copper foil negative electrode ( $15 \mathrm{~mm}$ diameter, MTI Corporation), Celgard 2325 separator (19 mm diameter) for electrolytes with ethylene carbonate:ethyl methyl carbonate (3:7, volume:volume) (EC:EMC) solvents (all electrolyte components were supplied from BASF as battery grade and used as received) or Celgard 3501 separator (19 mm diameter) when $\mathrm{VC}$ was employed as a solvent, and a $\mathrm{LiFePO}_{4}$ positive electrode ( $91 \%$ active material, $13.7 \mathrm{~mm}$ diameter, MTI corporation), the other $9 \%$ of the composite electrode is composed of conductive carbon and PVDF coated on aluminum. These components were soaked with $75 \mu \mathrm{L}$ of electrolyte (supplied from BASF). Electrolytes investigated were 1.2 $\mathrm{M} \mathrm{LiPF}_{6}$ in EC:EMC (EC:EMC electrolyte), EC:EMC electrolyte with $1 \%$ VC (mass $\%)$ (1\% VC electrolyte), EC:EMC electrolyte with 5\% VC (mass\%) (5\% VC electrolyte), and 1.2 $\mathrm{M} \mathrm{LiPF}_{6}$ in $\mathrm{VC}$ solvent (VC-S electrolyte). The copper foil was sonicated with $1 \mathrm{M} \mathrm{HCl}(2 \times 2$ minutes $)$ followed by sonication with isopropanol $(1 \times 2$ minutes $)$, punched to the specified diameter, and dried at $110^{\circ} \mathrm{C}$, overnight under vacuum (approx. $3 \times 10^{-3} \mathrm{~atm}$ ) prior to cell assembly. The $\mathrm{LiFePO}_{4}$ electrodes were punched to the specified diameter, and dried at $110^{\circ} \mathrm{C}$ overnight under vacuum (approx. $3 \times 10^{-3} \mathrm{~atm}$ ) prior to cell assembly. Cell assembly and disassembly was conducted in an argon glove box (M-Braun) with water and oxygen contents $<1 \mathrm{ppm}$. The cycling procedure consisted of plating lithium at $0.1 \mathrm{~mA} / \mathrm{cm}^{2}$ (approx. $\mathrm{C} / 20$ rate, where $\mathrm{C}$ represents the theoretical capacity of $\mathrm{LiFePO}_{4}$ ) with subsequent stripping and plating at $0.5 \mathrm{~mA} / \mathrm{cm}^{2}$ (approx. $\mathrm{C} / 4$ rate), within a voltage window of 2.0-4.0 V, using an Arbin BT2000 battery cycler at $25^{\circ} \mathrm{C}$. There was a rest period of one hour between cell construction and the beginning of the electrochemical protocol.

ATR-IR.-IR measurements were conducted on a Bruker Tensor 27 spectrometer equipped with an attenuated total reflection (ATR) accessory (Pike Technologies) containing a diamond/ZnSe reflection crystal plate and LaDTG detector. Lithium was plated onto copper foil according to the first charge procedure outlined in the Electrochemistry section (charge to $4.0 \mathrm{~V}$ at $\mathrm{C} / 20$ rate) and held at rest for approx. 48 hours to ensure cell equilibration before disassembly. Electrodes were washed with $4 \times 500 \mu \mathrm{L}$ battery grade EMC and dried overnight under vacuum (approx. $3 \times 10^{-3} \mathrm{~atm}$ ). The electrodes were transferred from the argon glove box to the nitrogen-filled glove box in a sealed glass vial and immediately analyzed. The spectra were acquired in the nitrogen glove box with a resolution of $4 \mathrm{~cm}^{-1}$ and 256 scans. An atmospheric compensation, baseline correction, and extended ATR correction were applied to all spectra using OPUS software, version 7.0. There is no evidence for reaction of the lithium metal anodes with the $\mathrm{N}_{2}$ during the timeframe of the analysis.

XPS.-XPS measurements were acquired with a K-alpha, Thermo system using $\mathrm{Al} \mathrm{K} \alpha$ radiation $(\mathrm{h} \nu=1486.6 \mathrm{eV}$ ) under ultra-high 

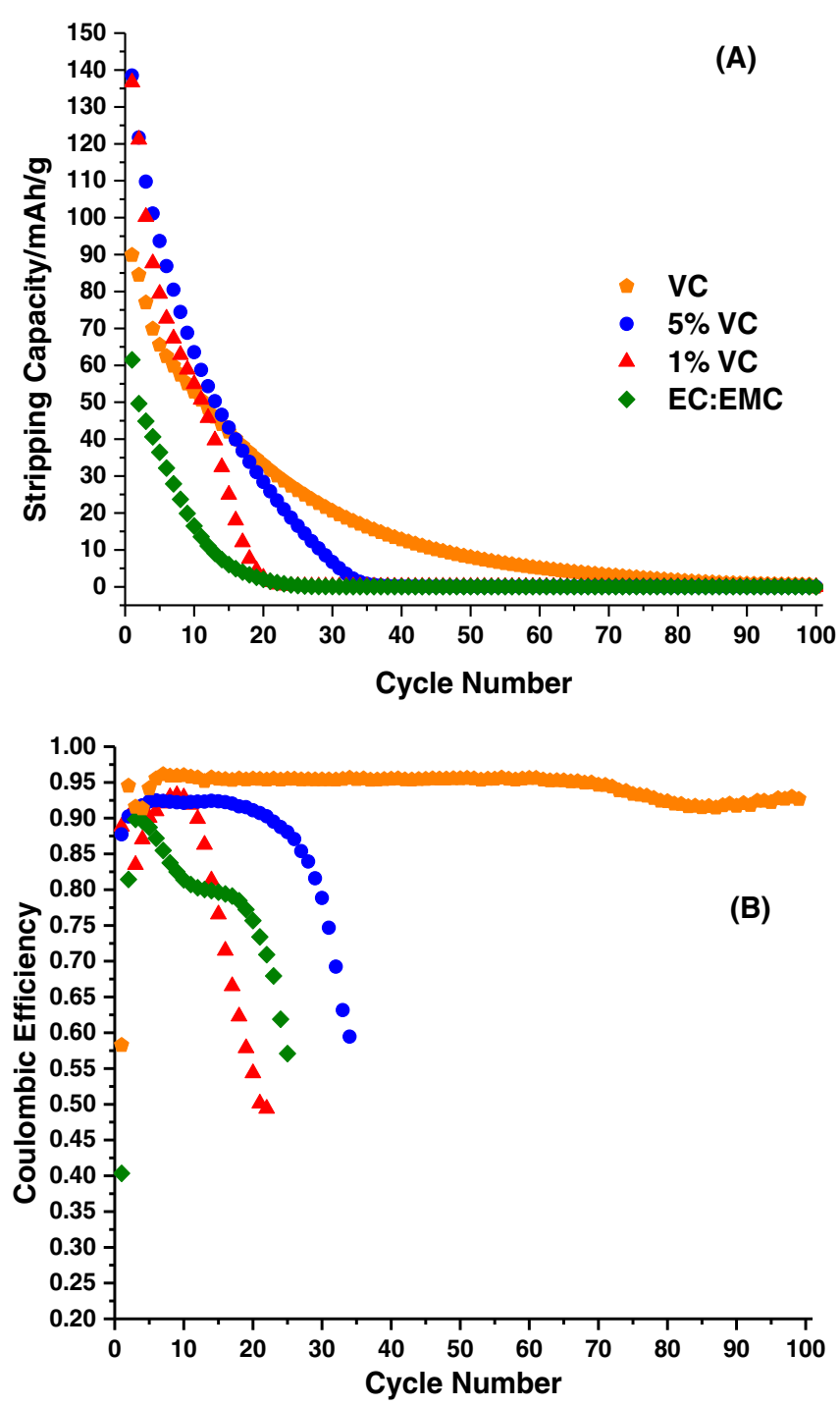

Figure 1. Stripping specific capacity vs. cycle number for the EC:EMC, $1 \%$ VC, 5\% VC, and VC-S electrolytes (A) and corresponding coulombic efficiency vs. cycle number (B).

vacuum $\left(<1 \times 10^{-12} \mathrm{~atm}\right)$ and a measured spot size of $400 \mu \mathrm{m}$ in diameter. Lithium was plated onto copper foil from a $\mathrm{LiFePO}_{4}$ cathode charged to $4.0 \mathrm{~V}$ at a rate of $\mathrm{C} / 20$ and held for 48 hours to ensure cell equilibration before disassembly. Electrodes were washed with $4 \times 500 \mu \mathrm{L}$ battery grade EMC and dried overnight under vacuum $\left(\sim 2 \times 10^{-10} \mathrm{~atm}\right)$. The samples were transferred from the argon glove box in an air-free transfer case. The binding energy was corrected based in the F1s spectrum, assigning $\mathrm{LiF}$ to a position of $685 \mathrm{eV}$. Relative atomic concentrations were calculated by integrating respective peaks with a Shirley background, using Thermo Avantage v5.932 software. Atomic concentrations were determined from integrations of the XPS peaks taking respective atomic sensitivity factors into account.

\section{Results and Discussion}

Electrochemical analysis.-The cycling performance of the carbonate electrolytes investigated is provided in Figure 1 with stripping capacity (Figure 1A), normalized using the active mass of $\mathrm{LiFePO}_{4}$, and coulombic efficiency (Figure 1B) versus cycle number. Since there is no excess lithium in the $\mathrm{Cu}|| \mathrm{LiFePO}_{4}$ cells, the reversible capacity of all cells decreases significantly over a short number of cycles as

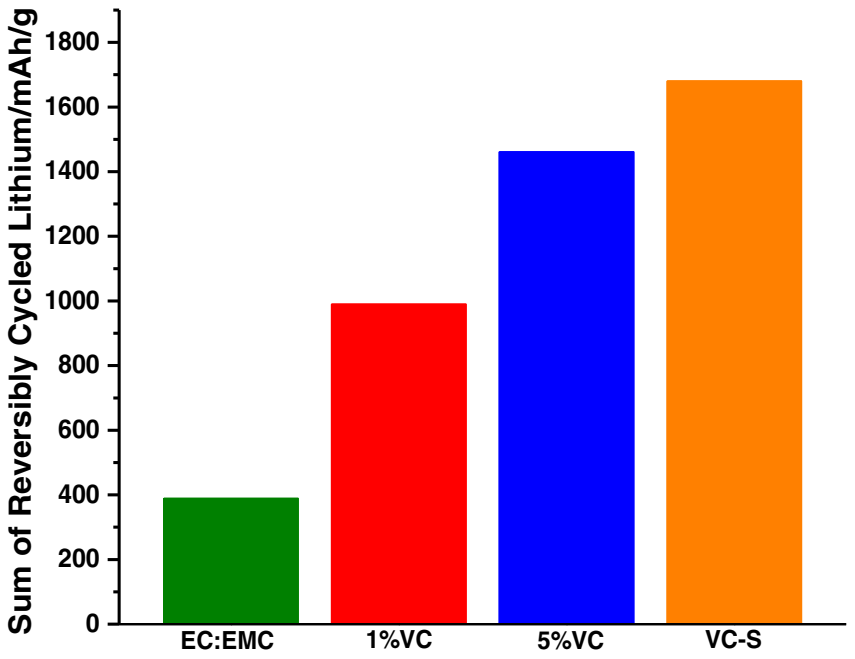

Figure 2. Total sum of reversibly cycled lithium after 100 cycles for the EC:EMC, $1 \%$ VC, $5 \%$ VC, and VC-S electrolytes.

expected. ${ }^{15}$ Since VC has been shown to have virtually no reactivity on $\mathrm{LiFePO}_{4}$, the improvement in cell performance is likely due to modification of the SEI on the negative electrode. ${ }^{22,29}$ In general, the addition of VC improves the capacity retention and the coulombic efficiency, as observed with the EC:EMC, $1 \%$ VC, $5 \%$ VC, and VC-S electrolytes. Electrolytes containing $1 \%$ and $5 \% \mathrm{VC}$ have the highest first cycle coulombic efficiency $\sim 87 \%$. The $5 \%$ VC electrolyte has a longer cycle life and better efficiency ( $\sim 92 \%)$, suggesting that increased concentrations of $\mathrm{VC}$ in the electrolyte results in the generation of a more stable SEI for lithium metal anodes. However, when employing $\mathrm{VC}$ as the solvent the first cycle coulombic efficiency is reduced significantly to $\sim 58 \%$. After the first cycle, the efficiency improves to $\sim 95 \%$, comparable to reports in the literature. ${ }^{10,25}$ After a significant quantity of lithium is consumed irreversibly on the first cycle, the VC-S electrolyte plates and strips lithium more efficiently than the EC:EMC, $1 \%$ VC, or 5\% VC electrolytes, leading to improved reversible cycling.

The total quantity of lithium stripped each cycle (or the lithium reversibly cycled), summed over all cycles, for each electrolyte is plotted in Figure 2. This plot demonstrates that the amount of lithium reversibly cycled is increased with increasing concentration of $\mathrm{VC}$ in the electrolyte. However, the increase of reversibly cycled lithium is not as dramatic when employing VC as a solvent. While increasing the concentration of $\mathrm{VC}$ in the electrolyte is beneficial for cycling performance, the beneficial effects diminish at high concentrations of VC.

The first cycle voltage vs. specific capacity plots for all electrolytes investigated are shown in Figure 3. The initial plating curves are very similar for all electrolytes, but the stripping voltage curves illustrate the high initial coulombic efficiency for the 1 and 5\% VC electrolytes. Increasing the concentration of VC in the electrolyte increases the hysteresis, consistent with the generation of a resistive SEI. This suggests that the diminishing benefit of $\mathrm{VC}$, discussed above, may result from high resistance of the SEI film.

ATR-IR analysis.-ATR-IR spectra of lithium plated on copper foil were acquired after the first charge to $4.0 \mathrm{~V}$ at $0.1 \mathrm{~mA} / \mathrm{cm}^{2}$ for the EC:EMC and 5\% VC electrolytes and are provided in Figure 4. The background for the diamond/ZnSe ATR crystal spectrum is also provided to depict spectral artifacts from the ATR crystal. $\mathrm{Li}_{2} \mathrm{CO}_{3}$ is present on lithium plated from both the EC:EMC and 5\% VC electrolytes as evidenced by characteristic peaks ${ }^{30,31}$ between $1550-1400$ $\mathrm{cm}^{-1}$ and at $\sim 875 \mathrm{~cm}^{-1}$. In addition, a peak characteristic of lithium alkyl carbonates ${ }^{30,32}$ is observed between $1700-1650 \mathrm{~cm}^{-1}$ for the lithium plated with the EC:EMC electrolyte. However, IR absorptions 


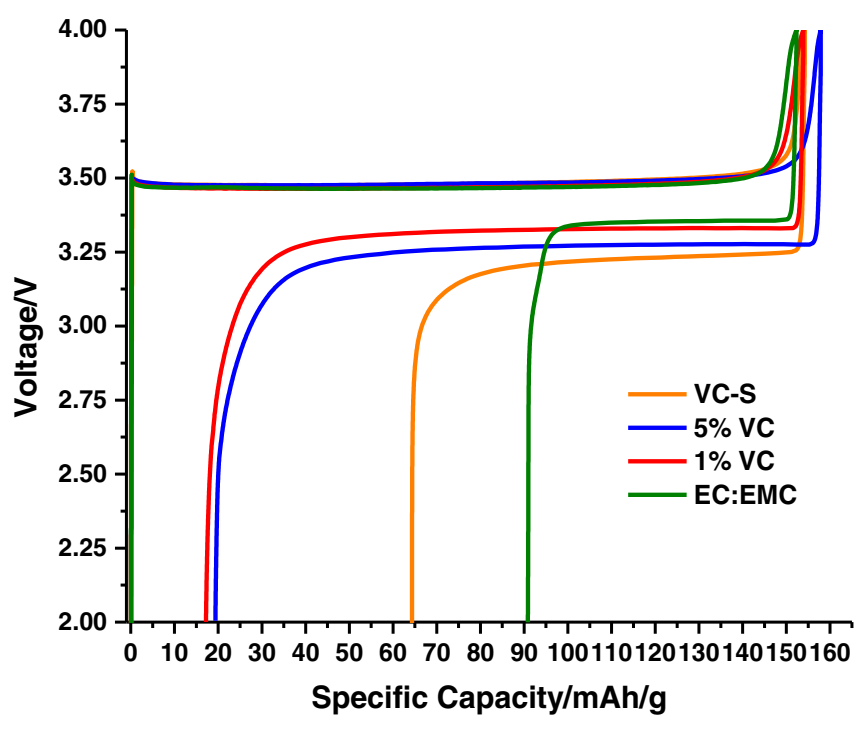

Figure 3. Voltage vs. specific capacity plots for the first plating and stripping of lithium with EC:EMC, $1 \% \mathrm{VC}, 5 \% \mathrm{VC}$, and VC-S electrolytes.

characteristic of lithium alkyl carbonates are not observed for lithium plated with the 5\% VC electrolyte. Instead, strong absorptions are observed between $1850-1750 \mathrm{~cm}^{-1}$ and $1200-1050 \mathrm{~cm}^{-1}$, consistent with the presence of poly(VC) as previously reported. ${ }^{26,33}$

XPS analysis.-XPS spectra of lithium plated on copper foil were acquired after the first charge to $4.0 \mathrm{~V}$ at $0.1 \mathrm{~mA} / \mathrm{cm}^{2}$. The $\mathrm{C} 1 \mathrm{~s}$ XPS spectra for electrodes plated from the EC:EMC and 5\% VC electrolytes are plotted in Figure 5. The $\mathrm{C} 1 \mathrm{~s}$ spectra for the electrode plated from EC:EMC contains peaks characteristic of $\mathrm{Li}_{2} \mathrm{CO}_{3}$ or lithium alkyl carbonates at $290 \mathrm{eV}^{31,32}$ along with a $\mathrm{C}-\mathrm{O}$ peak at $686.7 \mathrm{eV}$, consistent with the IR spectra. The XPS spectrum of the electrode plated from $5 \% \mathrm{VC}$ electrolyte, is very different and contains intense peaks at 291 and $288 \mathrm{eV}$ characteristic of Poly(VC) in the SEI, ${ }^{26}$ which is also consistent with IR spectra.

The O1s XPS spectra of Li plated with the EC:EMC and 5\% $\mathrm{VC}$ electrolytes are provided in Figure 5. The O1s spectrum for

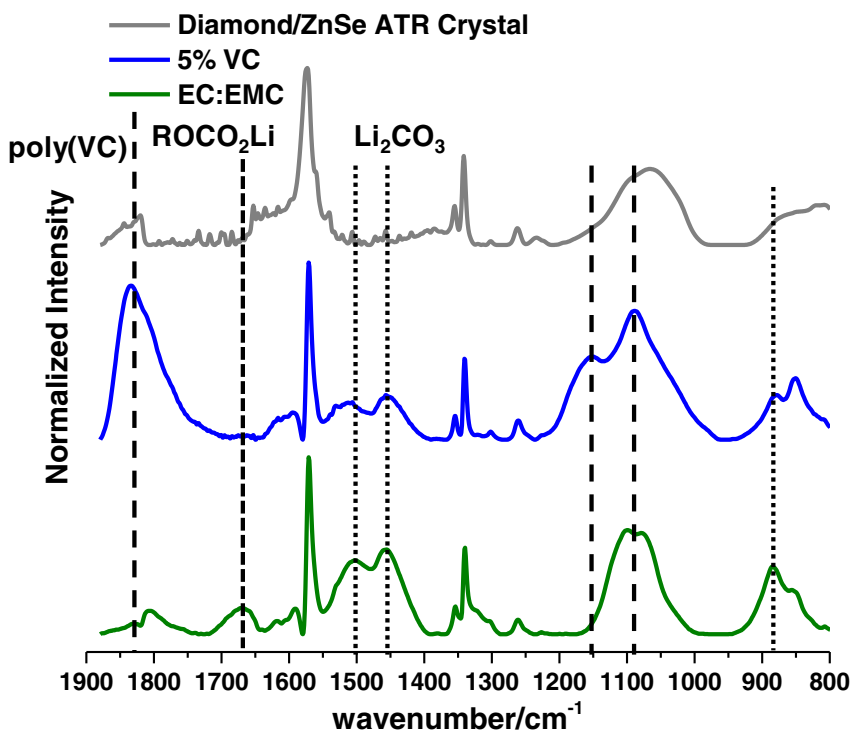

Figure 4. Normalized ATR-FTIR spectra of lithium plated with EC:EMC and $5 \% \mathrm{VC}$ electrolytes for regions $1900-800 \mathrm{~cm}^{-1}$. A spectrum of the diamond/ZnSe ATR crystal is shown to emphasize overlapping regions.

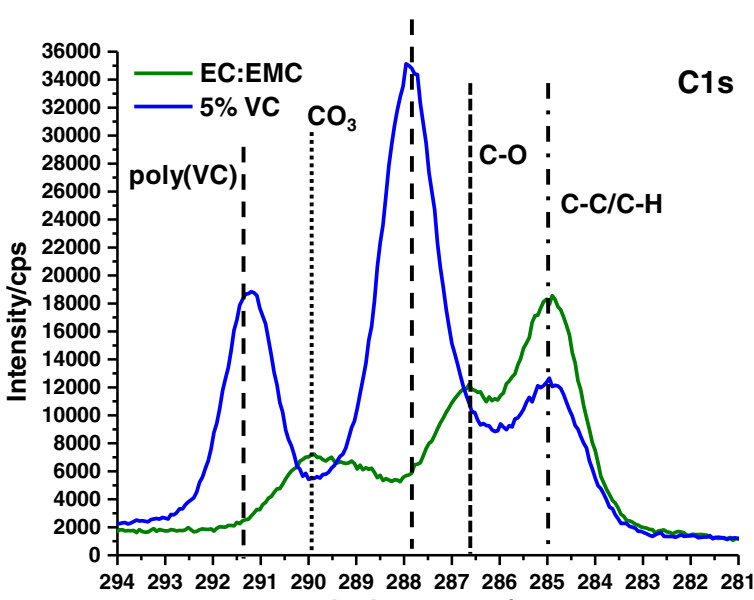

Binding Energy/eV
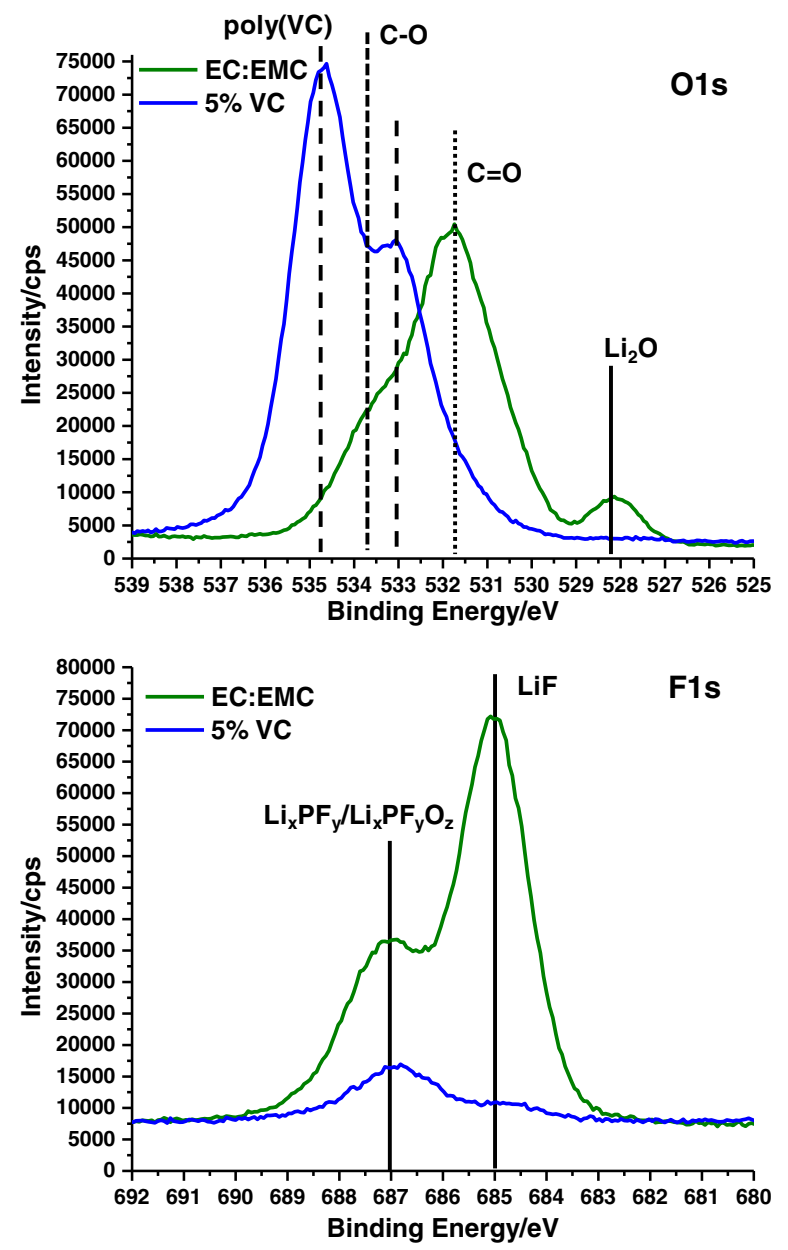

Figure 5. C1s, O1s, F1s XPS spectra plotted for lithium plated with EC:EMC and $5 \%$ VC electrolytes.

EC:EMC electrolyte, contains a peak characteristic of lithium carbonates $(\sim 531.5 \mathrm{eV})$, consistent with the $\mathrm{C} 1 \mathrm{~s}$ spectra. A peak characteristic of $\mathrm{Li}_{2} \mathrm{O}$ at $528 \mathrm{eV}$ is also present on the surface of the lithium metal plated from the EC:EMC electrolyte. ${ }^{34}$ The O1s spectrum for the $5 \% \mathrm{VC}$ electrolyte contains intense peaks at 534.5 and $533 \mathrm{eV}$ characteristic of Poly(VC) in the SEI, ${ }^{26}$ consistent with the $\mathrm{C} 1 \mathrm{~s}$ spectra. The F1s XPS spectra of Li plated with the EC:EMC and 5\% VC electrolytes are plotted in Figure 5. The F1s spectra for both the EC:EMC and 5\% VC electrolytes contain a broad peak characteristic of $\mathrm{Li}_{\mathrm{x}} \mathrm{PF}_{\mathrm{y}} / \mathrm{Li}_{\mathrm{x}} \mathrm{PF}_{\mathrm{y}} \mathrm{O}_{\mathrm{z}}{ }^{19}$ at $\sim 687 \mathrm{eV}$ and the related peaks are observed 

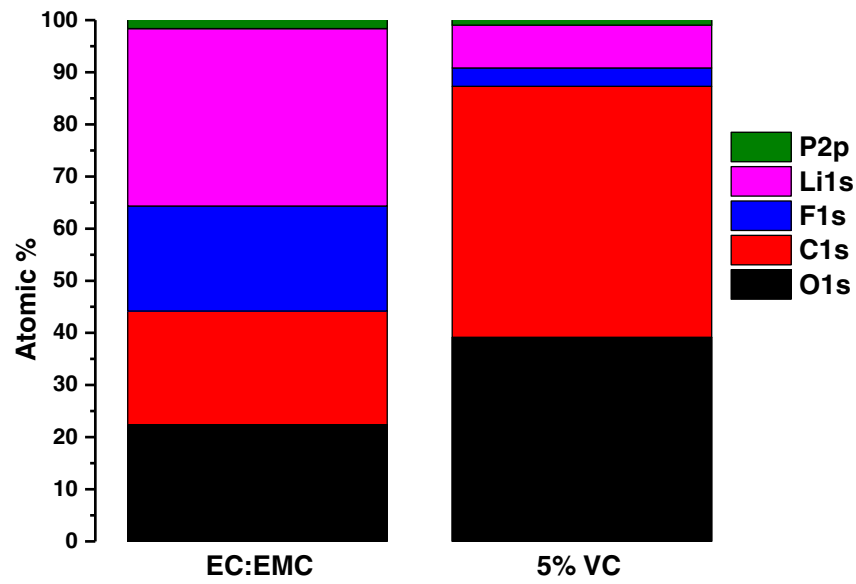

Figure 6. Corresponding relative atomic concentrations from XPS spectra for lithium plated with EC:EMC and 5\% VC electrolytes.

in the P2p spectra at $\sim 137 / 135 \mathrm{eV}$ (not shown). The XPS spectrum of the lithium plated from the EC:EMC electrolyte also contains a large peak at $685 \mathrm{eV}$ characteristic of $\mathrm{LiF}$. The peak associated with $\mathrm{LiF}$ is much smaller for the electrolyte containing VC suggesting that VC inhibits $\mathrm{LiPF}_{6}$ reduction. The surface of the SEI generated from the $5 \%$ VC electrolyte is primarily composed of poly( $\mathrm{VC})$.

A chart of the corresponding relative atomic concentrations is provided in Figure 6. The surface of the lithium plated from the 5\% VC electrolyte is primarily composed of organic species as evidenced by high concentrations of $\mathrm{C}$ and $\mathrm{O}$. The IR and XPS data suggest that the surface is dominated by poly(VC). Alternatively, the surface plated from the EC:EMC electrolyte has much higher concentrations of inorganic species, $\mathrm{Li}$ and $\mathrm{F}$, consistent with the presence of high concentrations of LEDC and LiF. Given the improvement of the electrochemistry, the results suggest that incorporating polymeric species into the SEI are beneficial for plating/stripping lithium.

\section{Conclusions}

The influence of vinylene carbonate (VC) on plating/stripping lithium was investigated using $\mathrm{Cu}|| \mathrm{LiFePO}_{4}$ cells. This allows for in-situ generation of lithium, ensuring controlled SEI formation compared to $\mathrm{Li}|| \mathrm{Cu}$ cells. Addition of $\mathrm{VC}$ has been found to improve the capacity retention of the cells, and increasing the concentration of $\mathrm{VC}$ in the electrolyte further improves the reversibility of lithium cycling. However, the performance improvements are accompanied by an increased voltage hysteresis. Ex-situ surface analysis of the electrodes suggests that the SEI generated on the plated lithium is primarily composed of $\mathrm{LEDC}, \mathrm{Li}_{2} \mathrm{CO}_{3}$, and $\mathrm{LiF}$ when the $1.2 \mathrm{M} \mathrm{LiPF}_{6}$ in EC:EMC (3:7) electrolyte is utilized. Alternatively, the SEI is dominated by poly(VC) when cells are cycled with the $1.2 \mathrm{M} \mathrm{LiPF}_{6}$ in EC:EMC (3:7) with 5\% VC electrolyte. The results suggest incorporating polymeric species within the lithium SEI improves plating/stripping performance of lithium metal in carbonate electrolytes. The results are similar to previously reported investigations with $\mathrm{Li} \| \mathrm{Cu}$ cells and demonstrate the feasibility of $\mathrm{Cu}|| \mathrm{LiFePO}_{4}$ cells for developing electrolytes for lithium metal electrodes. ${ }^{10,28}$ With this knowledge, advantageous characteristics of $\mathrm{Cu}|| \mathrm{LiFePO}_{4}$ cells can be exploited when investigating other electrolyte additives. Specifically, other additives which can generate polymer surface films are under investigation and will be reported in the future.

\section{Acknowledgments}

The authors gratefully acknowledge funding from Department of Energy Office of Basic Energy Sciences EPSCoR Implementation award (DE-SC0007074).

\section{References}

1. M. S. Whittingham, Science, 192, 1126 (1976)

2. R. D. Rauh, T. F. Reise, and S. B. Brummer, J. Electrochem. Soc., 125, 186 (1978).

3. K. Xu, Chem. Rev., 104, 4303 (2004).

4. F. Ossola, G. Pistoia, R. Seeber, and P. Ugo, Electrochim. Acta, 33, 47 (1988)

5. E. Plichta, S. Slane, M. Uchiyama, M. Salomon, D. Chua, W. B. Ebner, and H. W. Lin, J. Electrochem. Soc., 136, 1865 (1989).

6. I. Uchida and S. Hajime, J. Electrochem. Soc., 142, L139 (1995)

7. M. S. Whittingham, Proc. IEEE, 100, 1518 (2012)

8. W. Xu, J. Wang, F. Ding, X. Chen, E. Nasybulin, Y. Zhang, and J.-G. Zhang, Energy Environ. Sci., 7, 513 (2014)

9. D. Aurbach, O. Youngman, Y. Gofer, A. Meitav, and P. Dan, Electrochim. Acta, 35 , 625 (1990).

10. F. Ding, W. Xu, X. Chen, J.-G. Zhang, M. H. Engelhard, Y. Zhang, B. R. Johnson, J. V. Crum, T. A. Blake, X. Liu, and J.-G. Zhang, J. Electrochem. Soc., 160, A1894 (2013).

11. F. Ding, W. Xu, X. Chen, J. Zhang, Y. Shao, M. H. Engelhard, Y. Zhang, T. A. Blake, G. L. Graff, X. Liu, and J. G. Zhang, J. Phys. Chem. C, 118, 4043 (2014)

12. G. Bieker, M. Winter, and P. Bieker, Phys. Chem. Chem. Phys., 17, 8670 (2015)

13. J. Qian, W. A. Henderson, W. Xu, P. Bhattacharya, M. Engelhard, O. Borodin, and J.-G. Zhang, Nat. Commun., 6, 6362 (2015).

14. E. Peled, J. Electrochem. Soc., 126, 2047 (1979).

15. J. Qian, B. D. Adams, J. Zheng, W. Xu, W. A. Henderson, J. Wang, M. E. Bowden, S. Xu, J. Hu, and J. G. Zhang, Adv. Funct. Mater, 26, 7094 (2016).

16. B. J. Neudecker, N. J. Dudney, and J. B. Bates, J. Electrochem. Soc., 147, 517 (2000),

17. C. Jehoulet, P. Biensan, J. M. Bodet, M. Broussely, C. Moteau, and C. Tessier-Lescourret, Batteries for Portable Applications and Electric Vehicles, A. R. Landgrebe and C. F. Holmes, Editors, p. 974, The Electrochemical Society, (1997).

18. D. Aurbach, K. Gamolsky, B. Markovsky, Y. Gofer, M. Schmidt, and U. Heider, Electrochim. Acta, 47, 1423 (2002).

19. M. Nie, J. Demeaux, B. T. Young, D. R. Heskett, Y. Chen, A. Bose, J. C. Woicik, and B. L. Lucht, J. Electrochem. Soc., 162, A7008 (2015).

20. B. Zhang, M. Metzger, S. Solchenbach, M. Payne, S. Meini, H. A. Gasteiger, A. Garsuch, and B. L. Lucht, J. Phys. Chem. C, 119, 11337 (2015).

21. H. Ota, Y. Sakata, A. Inoue, and S. Yamaguchi, J. Electrochem. Soc., 151, A1659 (2004).

22. L. El Ouatani, R. Dedryvère, C. Siret, P. Biensan, and D. Gonbeau, J. Electrochem. Soc., 156, A468 (2009).

23. J. C. Burns, R. Petibon, K. J. Nelson, N. N. Sinha, A. Kassam, B. M. Way, and J. R. Dahn, J. Electrochem. Soc., 160, A1668 (2013).

24. R. Petibon, L. Rotermund, K. J. Nelson, A. S. Gozdz, J. Xia, and J. R. Dahn, J. Electrochem. Soc., 161, A1167 (2014).

25. H. Ota, K. Shima, M. Ue, and J. ichi Yamaki, Electrochim. Acta, 49, 565 (2004).

26. H. Ota, Y. Sakata, Y. Otake, K. Shima, M. Ue, and J. Yamaki, J. Electrochem. Soc., 151, A1778 (2004).

27. R. Mogi, M. Inaba, S.-K. Jeong, Y. Iriyama, T. Abe, and Z. Ogumi, J. Electrochem. Soc., 149, A1578 (2002).

28. J. Guo, Z. Wen, M. Wu, J. Jin, and Y. Liu, Electrochem. Commun., 51, 59 (2015).

29. R. Dedryvère, M. Maccario, L. Croguennec, F. Le Cras, C. Delmas, and D. Gonbeau, Chem. Mater, 20, 7164 (2008).

30. D. Aurbach and A. Zaban, J. Electroanal. Chem., 365, 41 (1994)

31. D. M. Seo, C. C. Nguyen, B. T. Young, D. R. Heskett, J. C. Woicik, and B. L. Lucht, J. Electrochem. Soc., 162, A7091 (2015).

32. K. Xu, G. R. V Zhuang, J. L. Allen, U. Lee, S. S. Zhang, P. N. Ross, and T. R. Jow, J. Phys. Chem. B, 110, 7708 (2006).

33. A. L. Michan, B. S. Parimalam, M. Leskes, R. N. Kerber, T. Yoon, C. P. Grey, and B. L. Lucht, Chem. Mater., 28, 8149 (2016).

34. J. F. Moulder, W. F. Stickle, P. E. Sobol, and K. D. Bomben, Handbook of X-ray Photoelectron Spectroscopy, J. Chastan, Editor, p. 11, Perkin-Elmer Corporation, (1992). 